13. Uehara A, Hirabayashi Y, Takada H. Antibodies to proteinase 3 prime human oral, lung and kidney epithelial cells to secrete proinflamatory cytokines upon stimulation with agonists to various Toll-like receptors, NOD1, and NOD2. Clin Vaccine Immunol 2008;15:1060-6.

14. Harper L, Ren Y, Savill J, et al. Antineutrophil cytoplasmic antibodies induce reactive oxygendependent dysregulation of primed neutrophil apoptosis and clearance by macrophages. Am J Pathol 2000;157:211-20.

15. Richter A, Stockley RA, Harper L. Pulmonary infection in Wegener's granulomatosis and idiopathic pulmonary fibrosis. Thorax 2009;64:692-7.

16. Pinching AJ, Rees AJ, Pussell BA, et al. Relapses in Wegener's granulomatosis: the role of infection. $B M J$ 1980;281:836-8.
17. Stegeman CA, Tervaert JW, Sluiter WJ, et al. Association of chronic nasal carriage of Staphylococcus aureus and higher relapse rates in Wegener's granulomatosis. Ann Intern Med 1994:120:12-4.

18. Meduri GU, Kanganat S, Stefan E, et al. Cytokines IL-1 beta, IL-6 and TNF alpha enhance in vitro growth of bacteria. Am J Respir Crit Care Med 1999:160:961-7.

19. Kanangat S, Bronze MS, Meduri GU, et al. Enhanced extracellular growth of Staphylococcus aureus in the presence of selected linear peptide fragments of human interleukin (IL)-1 beta and IL-1 receptor antagonist. J Infect Dis 2001;183:65-9.

20. DeRemee R, McDonald TJ, Weiland LH. Wegener's granulomatosis: observations on treatment with antimicrobial agents. Mayo Clin Proc 1985;60:27-32.

21. DeRemee R. The treatment of Wegener's granulomatosis with trimethoprim/ sulphamethoxazole: illusion or vision? Arth Rheum 1988;31:1068-72.

22. Vannella $\mathbf{K M}$, Moore BB. Viruses as co-factors for the initiation or exacerbation of lung fibrosis.

Fibrogenesis Tissue Repair 2008;1:2

23. Stewart JP, Egan JJ, Ross AJ, et al. The detection of Epstein-Barr virus DNA in lung tissue from patients with idiopathic pulmonary fibrosis. Am J Respir Crit Care Med 1999;159:1336-41.

24. Tang YW, Johnson JE, Browning PJ, et al Herpesvirus DNA is consistently detected in lungs of patients with idiopathic pulmonary fibrosis. J Clin Microbiol 2003;41:2633-40.

25. Varney VA, Parnell HM, Salisbury DT, et al. A double blind randomized placebo controlled pilot study of oral co-trimoxazole in advanced fibrotic lung disease. Pulm Pharmacol Ther 2008;21:178-87.

\title{
Where there's smoke... there's tuberculosis
}

\section{Stephen Gordon, Jamie Rylance}

Recent observations have demonstrated precisely the increased life expectancy associated with clean environmental air in the USA. ${ }^{1}$ This dramatic health benefit has been achieved at levels of pollution very much lower than those found indoors in underdeveloped countries. Traditional cooking fires using biomass (organic material) fuel are inefficient and the smoke levels measured in poorly ventilated homes are often 100 times that regarded as dangerous in the affluent industrial world. High levels of indoor air pollution have been associated in epidemiological studies with upper and lower respiratory tract acute infections (ALRIs), chronic obstructive pulmonary disease (COPD) and lung cancer. ${ }^{2}$ There has been less evidence to support an association of indoor air pollution with biomass fuel use and tuberculosis, and so the report by Kolappan and Subramani (see page 705) in this issue is most welcome.

Three billion people use biomass fuel globally, almost entirely in areas with high rates of tuberculosis. The confounding effects of poverty, crowding, malnutrition and increased exposure make an association between biomass fuel use and tuberculosis very hard to dissect. In a well-conducted study in Chennai, India, the authors report that $36 \%$ of proven tuberculosis cases can be associated with biomass fuel usage. Confounding factors including cigarette smoking, alcohol use, socioeconomic status and case-contact are

Correspondence to: Dr Stephen Gordon, Liverpool School of Tropical Medicine, Pembroke Place, Liverpool L3 50A, UK; sbgordon@liverpool.ac.uk also examined. This study is likely to underestimate the true burden of tuberculosis transmission as young children are intensely exposed to biomass smoke in the home and are a very difficult group in which to diagnose tuberculosis.

Given the association of ALRIs with biomass smoke exposure, and the association of cigarette smoking with tuberculosis, the finding of this study is not surprising. Two major unanswered questions are immediately provoked. First: what is the mechanism behind this association? Secondly: what can be done to protect biomass smoke-exposed adults and children in areas with high tuberculosis transmission?

The mechanism by which biomass smoke exposure results in increased tuberculosis disease is likely to relate to established effects on alveolar macrophages and pulmonary epithelium. Smoke particle size, form and surface chemistry initially promote a proinflammatory state and oxidative damage to the lung. Laboratory models have demonstrated upregulation of tumour necrosis factor $\alpha$ (TNF $\alpha$ ), interleukin 6 (IL6) and IL8, nuclear factor- $\kappa \mathrm{B}(\mathrm{NF}-\kappa \mathrm{B})$ activation and cellular lipid peroxidation. Apoptosis of alveolar macrophages is also increased, and, although this is usually considered a positive host defence response, cytotoxic effects may predominate. Phagocytosis is reduced in some non-tuberculosis bacterial studies, and pulmonary mycobacterial load is increased by diesel exhaust participates. Peak respiratory burst activity may be decreased, but inducible nitric oxide synthase (iNOS) expression is upregulated. There is no clear narrative to this disruption, and many as yet uninvestigated possibilities. As the epidemiological evidence becomes stronger, there is a need to strengthen mechanistic explanations using relevant in vitro models of biomass particulates.

More importantly to the 7 million people per year who are diagnosed as having tuberculosis in underdeveloped countries, what can be done to prevent this burden of disease? The answer here can be stated with more certainty. Multiple new technologies exist to improve fuel efficiency and domestic ventilation, even in the most resourcedeprived situations (www.hedon.info). At the Partnership for Clean Indoor Air Forum in Kampala in March 2009 (www.pciaonline.org), 265 non-governmental organisations (NGOs) re-asserted their intention to improve indoor air quality not only because of the environmental imperative to do so, but also because of the probable health benefits of improved stove technology.

As chest physicians, we look forward to the results of the RESPIRE trial from Guatemala, due to be published this year, which is expected to show for the first time a direct health benefit from an indoor air intervention. A stove intervention alone, however, will not reduce the global burden of tuberculosis.

Reducing biomass smoke-related disease will require multifaceted action to improve fuel security, health education (particularly for women), diet and environmental conservation coupled with excellent tuberculosis case management. These are exciting and challenging times.

Competing interests: None.

Thorax 2009;64:649-650. doi:10.1136/thx.2009.116400

\section{REFERENCES}

1. Pope CA 3rd, Ezzati M, Dockery DW. Fine-particulate air pollution and life expectancy in the United States. N Engl J Med 2009;360:376-86. 
2. Torres-Duque C, Maldonado D, Pérez-Padilla R, et al. Biomassfuels and respiratory: a review of the evidence. Proc Am Thorac Soc 2008;5:577-90.
3. Kolappan C, Subramani R. Association between biomass fuel and pulmonary tuberculosis: a nested case-control study. Thorax 2009;64:705.
4. Hopewell PC, Pai M, Maher D, et al. International standards for tuberculosis care. Lancet Infect Dis 2006;6:710-25. 